\title{
A PHILOSOPHICAL RE-APPRAISAL OF TEACHER EDUCATION AND VALUE RE-ORIENTATION IN NIGERIA: PROGNOSIS FOR UTOPIAN SOCIETY
}

\section{OYEWUMI, KASSIM A.}

\begin{abstract}
This paper deals with re-appraisal of Teacher Education and value re-orientation as they affect Nigeria educational system. Especially on the quality of teachers who implement government policies on education. References were made to good old days in Africa when morality, honesty and sincerity pervade every where unlike now that foreign culture has bastardized our value. The concept of value and value re-orientation was revisited to ascertain what are acceptable to Africans as a group of people which their education process should reflect.
\end{abstract}

Key words: Teacher Education, Value and Value re-orientation.

\section{INTRODUCTION}

Education has been unequivocally identified as a veritable means of igniting positive changes in any society where it is well implemented. However, education can not unilaterally perform this function without the effort of well trained teachers who are expected to be harbingers of functional and moral laden education. An education which has the colouration of the value of the immediate environment only possesses the potency to assure a utopian society.

To this effect, a part of the National Policy on Education which is the Federal Government of Nigeria's blueprint on educational polices purports that no society could rise above the level of her teachers. This assertion among many others points to the fact that teachers could also be held responsible for the moral laxity which has become order of the day among the youths of Nigeria.

Therefore, one thinks that the process of teacher education along with the generally acceptable morals of Nigeria as a society, need re-appraisal with the view to see what has gone wrong with the kind of teaching or training given to the youths. The above highlighted factor makes it imperative upon the writer of this paper to re-examine the aspect of Teacher education as the spring board of the exhibited behaviours among Nigerian citizenry. Hence, there is need to discuss teacher education.

\section{Teacher-Education in Retrospect}

Teacher education appears not recognized like other disciplines such as law, medicine, architect and so on, where not every Jack and Harry could be admitted. One thinks this is one of the reasons why teaching profession was not accorded the prestige due for a professional discipline. So, anybody could find his steps into teaching profession and thus be addressed as a teacher. At any rate, the National Policy on Education (2004) recognizes institutions where teachers are to be trained before they qualify to teach in any formal education setting. 
At this juncture, a question comes up that is it only those trained in the teachers' institutions are regarded as teachers? This could be a major problem that befalls teachers at the expense of their chosen career. All others who are not trained are also imparting knowledge to learners. And this has affected the quality of education received by individuals especially in Nigeria.

Nevertheless, in order not to loose focus of our discussion. there is need to accept that there is a teacher education as stipulated by government policy statement. So, who is a teacher? A teacher could be described as one who is trained with the necessary skills to organize, arrange, direct and guide others with a view to restructure an individual to become a worthwhile and rational being. In the idea of Abiogu and Enemuo (2007):

"A teacher is the architect
who designs the
superstructure on which
education revolves."
$(p .36)$

This scholarly assertion emphasizes the strategic position a teacher occupies in the process of education. It is therefore the reason for government decision to dissipate energy toward the training of teachers as enshrined in her policy statement on education.

To this effect, various institutions were established to cater for the training of teachers. Among these are National Teachers' Institute (NTI) Kaduna, Colleges of Education, and Faculty of Education in the Universities. Institute of Education and Teacher Training Colleges. A question to be asked at this point is that since the establishment of these institutions, has government deemed it fit to review the curriculum being run in these schools to cater for value re-orientation? The possible answer could be no because if this had been done adequately having the contributions from concerned individuals the level of moral decadence in our society today would have been curtailed before its present escalation.

The moral decadence such as immoral dressing among students, examination malpractices, corruption, and so on should have been nipped in the bud if actually the teacher education in existence were overhauled. The implication of this is that the teacher themselves lack the moral justification to correct moral laxities among the students across different levels of education in Nigeria.

This phenomenon has been blamed by some scholars on the imported Western Philosophy of Education which is in sharp contrast with African indigenous educational philosophy that is in consonance with our yelling and aspiration. Although, at a point, the education system was said to be reviewed which brought into existence the present philosophy of education; but Akinpelu (1981), observed that those to effect changes were the product of the system they intended to change, and therefore find it difficult to effect any changes rather we revolve around the bequeathed legacy.

Besides, Nigerian teacher education system has been tailored towards technological advancement which now sees teachers of science as superior and most needed at the expense of humanity studies teachers. This balkanization caused 
by the government policy actions have undermined the good work of teachers. Apart frcm the foregoing, it appears as if the thics which form theoretical bases for morality is not given due prominence in the training of teachers which bounces back on their products (students). Some teachers personally lack good moral behaviour which could have served as model to students. An adage says: one cannot give what he does not possess. Similarly, teachers who lack good moral cannot inculcate morality in students they nurture. This further exposes the reason why the problem of examination malpractices, bribery, and other vices become die hard syndrome because teachers are also involved. A teacher who is to condemn a bad habit is even one who introduces new ones to the students.

How can a teacher who keeps a chain of illegal sexual partners among his students preach against illicit sex? Let alone discouraging provocative dressing among the female students. With these catalogues of negative actions from teachers, it appears imperative that teacher education system needs re-orientation. This then leads the study to the next discussion; value and value reorientation.

\section{Value and Value-Re-Orientation}

Value generally could be described as something worthwhile which majority accepted as being good, desirable and useful. According to Akinpelu (1981) he says that, "Values primarily refer to those objects which we cherish, appreciate, want, desire or need."(p.47). This definition appears to describe values as corporeal object or matter which we cherish. appreciate or want, but values, at times could be intangible thing such as behaviour or character. In a revised version of the definition therefore, Bamisaiye (1989) defines values as,"The worth, merit or esteem which we ascribe to a person, an object or idea". (p.50)

One agrees with this definition because it truly described values. Value describes the kind of position in which we place certain idea or way of doing things. However, different communities, especially in Nigeria with multi-cultural dimensions attached importance to faithfulness and submissiveness. For instance, the Yoruba race and even the whole of Nigeria before the advent of colonization cherish, appreciate, want and desire good behaviour, and this is what brought about the name "Omoluabi "i.e. well behaved person. In the traditional Nigerian setting our society detest bad behaviour, immoral dressing, and stealing, extra-judicial killings, among others which are the order of the day nowadays. So, due to the value ascribed to the supposedly ideal behaviour in the society, people were mindful of there dealings until degeneration sets in the name of civilization brought by the westernization of culture.

Nevertheless, the scholar who gives the definition in her exegesis of the meaning says man love to be associated with anything valuable. This is more reason why good conduct among humanity is regarded as valuable. However, value reorientation could be identified as the factor which brought about relegation to our valued ways of life through the interplay between African culture and Western civilization. A culture of traditional African setting were in operation where life were meaningful to people 
and avarice were at the bearest minimal. Just as the foreign culture penetrated in to the good system, suddenly everything changed and strange behaviour began to manifest in the life of the Africans especially the youth. Human nudity became a thing of joy through various immoral dresses. Assassination became the means of settling conflict and as a result the former peaceful environment became chaotic and suspicion dominates human interpersonal relations.

By and large, the same factor that has heralded all those social vices still possesses the potency to correct the anomalies. So, our value reorientation is necessary if this generation wishes to exit the world of insecurity, moral decadence it plunges in the name of civilization. The process of achieving this shall be the concern of the next discussion where scholars' ideas and the newly formulated ones shall be examined as an avenue to discuss possible means of escaping from the tangle of calamity which culture mixing had caused this generation.

\section{The Way Forward}

The study has been able to establish that despite government concern for the development of teachers and teacher education, much have not been done to actually achieve the training and production of quality teachers in its all ramification: Teacher education is not given such good attention as given to professions like law and medicine which spellsout the ethics associated to their professions, which provide a high decorum profile for the professions and their practitioners.
Similarly, the researcher is able to discuss the genesis of the current predicament of Nigerian valued ways of life which had once guaranteed serene society worthy of living in. Unlike what the society battles with nowadays where society and its inhabitant are thrown into pandemonium and confusion, simply because of the adopted foreign ways of life that are alien to African context and Nigeria in particular.

Despite this, there is always a way out of any problem and these have even been discussed by scholars long times ago but with little attention given to them. So, this paper tends to point out some of these scholars' ideas as well as the new innovations which could provide the desired aim of building a utopian society through our educational system.

In NTUI (2008) suggestions for improvement in the teachers' attitudinal training, he opines that teachers need to be morally developed with emphasis on character and attitudinal uprightness. This suggests that there is need for moral education in the training of teacher or teacher education. Similarly, Fafunwa (1974) recommends that the teachers should possess an in depth understanding of cultural, moral, social and economic problems of the society.

It is believe that an in depth understanding of the moral and cultural values of the immediate environment where teaching activities take place shall determine the kind of model to be given to youngsters. Closely related to the expected activities that should characterize teacher education is the qualities identified by Redl and Wattenberg as cited by Eric Hoyle 
(1969). They postulate that among the sub-roles of teacher is representative of society i.e. inculcates moral precepts and as object of identification i.e. possess traits which children imitate.

All these good qualities could not be attained by teachers miraculously except they are fused into the curriculum that produces teachers. And apart from developing the curriculum to suit this purpose. there should be adequate monitoring of teachers activities to be assured that what they lean actually reflect in their conduct as practicing teachers after training.

Nevertheless, having this lofty idea in place is not enough to make teachers deliver the expected task of producing morally and mentally sound citizen. But certain conditions necessary for the plan to work as expected should be put in place by those at the helm of affairs. Therefore, teachers should be provided with better working condition as well as best living condition to lure them away from the innumerable opportunities existing outside their confines which could impinge upon the discharge of teachers' duties; especially teachers at primary and post primary schools.

On value re-orientation, a question ensures that is it only formal education that can engender value reorientation? What about those who do not go through formal education? Well, one may say no to these questions because not only formal education is recognized as a form of education. There are informal and non-formal educations. As a proof. Enoh (2007) observes that in the development of British during industrial revolution. success was accomplished by hard heads and clever fingers. These are categories of people under non-formal education.

Therefore, in an attempt to rebuild any society, philosophy suggests there should be reflection upon the existing structures. with a view to ascertain where the problem emanates so that necessary remedy action could be initiated. This explains the submission of Bamisaiye who describes philosophy as a baby of failure. In the same vain, a popular Yoruba dictum supports the assertion in one of its philosophical statements that, "B'omode subu a wo iwaju, B'agba ba subu a weyin wo."

The message in the above Yoruba traditional proverb is that if a child falls, he looks to the front but when an elderly person falls he looks back. The implication is that when an elder looks back after fallen, he wishes to know the cause of his downfall and to avoid potholes that might have caused the downfall in the future.

In the same token, to have value reorientation which is presently being championed by the Federal Government of Nigeria which is tagged 're-branding' with the slogan 'good people, great nation', there is need for Nigeria to examine its educational philosophy and see where it has failed in its responsibilities which now degenerates into a decayed society, particularly in the aspect of morality.

So, there is need for Nigeria to retrace its steps back to the old time when things were in order and the kind of orientation which people had then. Orientations like being ones brothers' keeper. the principle of 
communalism rather than the imbibed system of individualism, which bastardized African relationships. During the old time under reference, among the Yorubas, there used to be a slogan that, "Oju merin ni bi omo, igba oju ni wo."

This means that two parents give birth to a child but about two hundred parents train the child. That was the reason then, if a child misbehaves anywhere, just any adult could correct him and inflict the proportion of discipline for the offence committed. While stealing and other social vices were seen as bad plague and the offenders were treated with ignomity.

In conclusion therefore, to achieve this better citizen and better society, it calls for the support of authority, and the political class. Just as Nyerere $(1968 ; 272)$ said that, "Only when we are clear about kind of society we are trying to build can we design our educational service to serve our goals."

With the above submission of a politician and educationist Nigeria is not making effort to break away from the shackle of colonization by not developing her own educational policy that would reflect African values especially those values that are generally acceptable to everybody e.g. value of honesty, uprightness, sincerity and so on.

Therefore, the teacher education curriculum should be designed in such a way that these African values would be clearly enunciated and taught to the prospective teachers as well as the practicing teachers through in-service training and seminars. It is a known fact that one cannot give what he does not have, likewise teachers cannot teach what they do not know themselves.

\section{References}

Abiogu, G. C. \& Enemuo, P. C. (2007). Nigeria Teacher Education Reform: Implication for National Development. In Enoh (ed). Education Reforms in Nigeria: A Reader. Jos: Saniez Publishers

Akinpelu, J. A. (1981). An Introduction to Philosophy of Education. London \& Basingstoke: Macmillian Publishers

Bamisaiye, R. (1989). A Practical Approach to Philosophy of Education. Ibadan: AMD Publishers

Fafunwa, B. (1974). Perspective in African Education, Ibadan: Macmillan \& Co.

Federal Government of Nigeria. (2004). National Policy on Education $4^{\text {th }}$ Edition. Lagos: NERDC.

Hoyle, E. (1969). The Role of the Teachers. London \& Henley: Routledge \& Kegan Paul.

Ntui, V. (2008). A Philosophical Examination of the Quality Dimension of Teaching in Nigerian Universities. Unpublished M. Ed Project in Dept. of Teacher Education. University of Ibadan.

Nwazuoke, I. A.; Okediran, E. A. \& Moronkola, O. A. (2007). Education for Social Transformation. Ibadan: Faculty of Education University of Ibadan.

Nyerere, J. K. (1968) Freedom and Socialism. London: Oxford University Press.

Omoregbe. J. I. (ed.) (1998). Introduction to Philosophy and Logic. University of Lagos Press. 